\title{
Women empowerment through Self Help Groups-A case study of Barhampur Development Block in Nagaon District of Assam.
}

\author{
Ajit Borah. \\ Asstt.professor, Rukesen College, Dept.of Economics, Bakalia, KarbiAnglong, Assam.
}

\begin{abstract}
A self-help is a small, economically homogeneous and attractive group of 10-20 rural poor people which comes together to save small amounts regularly. It generally performs various types of economic activities with the help of their small savings. Women Self-help groups are informal association of women. The main purpose of such an association is to enable members to gain economic benefits out of mutual help, solidarity and social responsibility. Generally, the economic benefit includes mobilization of savings and credit facilities and to pursue group based economic activities. SHG approach is the group based approach, which helps the poor women members of each SHG to accumulate capital by way of small saving and helping them to get credit facilities from their funds. Presently, the poor women of the society are facing the financial problem to start business or to undertake different economic activities to become self-employed and self-reliant. The SHG can empower poor women by providing facilities like savings and credit in the economic development process of the society
\end{abstract}

Keywords: Microfinance, SHGs, Poverty, Poor Women, Women empowerment

\section{Introduction}

Micro-finance is a new banking concept to the unbankable people of the world. It brings credit, Savings, and other essential financial services within the reach of the millions of people globally, who are too poor to serve by regular banking network. Micro-finance is an innovation in credit market for the developing countries. It is a service provider for poor people who are unemployed; who are poor entrepreneur's component of financial sector for the development and alleviate poverty. It is treated as an important approach to poverty alleviation programs and enhancement of living standard, particularly, of women, in developing countries, like India. It has come to be regarded as a supplementary development paradigm which widens the financial service delivery system by linking the large rural population with formal financial institution. Micro-finance is the provision of providing very small loans that are repaid within short periods of time, and is essentially used by low income individuals and households. This type of finance enables and empowers to alleviate poverty. It is also a tool, which provides considerable economic and non-economic externalities to low-income households in developing countries. Further, its importance has been increased, because, it becomes a tool to exercise development priorities for governments in developing countries. Self-help Group plays an important role in developing rural women in self employment. Micro-finance through the self-help groups developed the entrepreneurial skills among rural women community and to get self employment Pandit Jawaharlal Nehru said," To awaken the people, it is women who much be awakened; once she is one on the move, the family moves, the village moves and nation moves." Now the women are awakened by the self-help group (Angel anila, 2012). Therefore, women are underprivileged section in the development process. They are economically, socially and politically deprived Self-Help Groups mobilize women latent-energy and teach them to earn their own livings. Micro-finance with self-help group plays an effective role for promoting women empowerment. It is not only an efficient tool to fight against poverty but also as means of promoting the empowerment of the most marginalized sections of the population especially, women.

The study area is Barhampur Development Block in the middle part of Nagaon district of Assam. It is located at a distance of 11 kilometres away from the district headquarter of Nagaon. The Block is bounded by Khatuwal Mauza at the North, it is bounded by the Mikir hill district at the East, the Kandali Mouza is at the South boundary and the Kachamari Mauza at the west side of study area. The geographical area of the Block is 144.70 sq.km.

\section{Review of Literature}

There are sufficient literatures on women SHGs in India. In Assam also some studies have been done on women SHGs. But, due to time and cost factor, a few of them have been reviewed in this research work.

Kartar Sing and Jain (1995) explained that there are some theoretical and empirical evidences in group Formation. They also mentioned that there are four stages of group's formation, such as, forming, storing, norming and performing. They have identified four factors which help in group formation. These factors are :( 
a) full participation (b) leadership quality (c) homogeneity among the members and (d) transparency in operation and function of the groups.

Kapoor (2001) studied the empowerment of Indian Women. He discussed, analysed and answered the questions faced by women SHG in India. He option that the gender discrimination still existed, as a result of which women SHGs were unable to achieve the expected goal of empowerment in the country.

Manimekalai (2004) in his article stated that SHG need the help of NGOs to run the income generating activates successfully. The bank officers should counsel and guide the women in selecting and implementing profitable income generating activities. He remarked that the formation of SHGs have boosted the self-image and confidence of rural women.

Das Gupta (2005) in his article says that a paradigm shift is required form finance sector reform to micro-finance reform in the country. SHGs should be included in the priority sector and loan should be made mandatory to them. The Micro-credit facilities must be monitored vigorously so that there may not be shortage of funds to SHGs

Gupta (2007) mentioned that SHGs have become most effective tools for women empowerment. The confidence level of women members of SHGs has been increased, as a result of which, both the family and society are at beneficial stage.

Kumar A. (2009) observed that this may lead to improved household-level outcomes with respect to health, education particularly education of the girl, child, nutrition and family planning.

Mansuri B, B. (2010) stated that micro-finance has gain a lot of significance and momentum in the last decade, India now occupies a significance and niche in global micro finance through promotion of self help groups (SHGs) under SHG-Bank Linkage Programme (SBLP) and the micro finance institution model. The Indian model offers greater promise and potential to address poverty as it is focused on building social capital through access financial services through linking with the mainstream. In its simplest term it means banking for poor.

Ankita Deka (2011) in her study titled, "Determinants of Women's Empowerment in India: Evidence from National Family Health Survey "taken the data for this study from National Family Health Survey (NFHS) which is a large-Scale, multi-round survey conducted a representative sample of households through-out India. Her research is in specific way able to quantify the nature and extent of gender discriminatory practices in India. The study demystifies popular projections in mass media of India's burgeoning economy and how it has transformed the economic and social milieu. It also provides a framework for social workers in India about how gender discrimination operates and also illuminates the loopholes in policy practice. Social workers will be advocate for progressive policy legislation as well as able to design interventions to bring about necessary change.

SaravanaKumar (2012) made an attempt to study empowerment of women and the inculcation of financial training and discipline amongst the poor will undoubtedly have long-term socio-economic benefits. The principles of self help and microcredit thus hold the key to economic and socio-cultural freedom for India's millions of poor, opening the gates of a hitherto untapped reservoir of human enterprise.

All the above the studies do not provide sufficient information about women SHGs involved in various economic activates. Therefore, a humble attempt has been made in this research works to study women SHGs and their performance in different economic activists in the Barhampur Development Block in Nagaon District of Assam.

\section{Objectives of the study:}

\section{Objectives and Hypothesis}

To evaluate the performance of selected women SHGs in Barhampur Development Block.

\section{Hypothesis:}

Rural credit helps members of women SHGs to start new business.

\section{Methodology}

The present study is covering 11 Gaon Panchayats under Barhampur Development Block in Nagaon District of Assam. The Primary data are collected from personal interviews, schedules and questionnaires. The secondary data are collected from block, panchayats, government publication, books and journals, etc. The various statistical methods such as, tables, figures, average, percentage and other related statistical techniques are used to analyze the collected data and information

The sampling method chosen for the above research design is total of 22 SHGs of Barhampur block is decided to select from 11 Gaon Panchayate,( i.e. Barhampur Panchayat, Halowagaon Panchayat, Puranigndam Panchayat, Bamuni Panchayat, Barbari Panchayat, Chapanala Panchayat, Balijuri Panchayat, Satargaon 
Panchayat, Kutanigaon Panchayat, Chalcheli Panchayat, Uriagaon Panchayat) by simple random sampling method. From each SHG, 5 members are taken for interview. The sample sizes of 110 SHG members.

\section{Period of study:}

The field study was conducted during the period of November 2009 to December 2013 and all data used in this study relates to this period only.

\section{Finding and Analysis}

The Women Self Help Groups have played a dynamic role in the economic development of Barhampur Dev. Block. They are engaged in agriculture operations, household industries, trade and commerce and other related economic activities. It has been observed in field survey that women are hard workers, adventurous; self determined and are willing to take risks in setting up new business. It is a tradition on the part of women to make efficient management of household affairs, but now-a-days, women are equally interested in setting up their own business enterprises to become independent and self-reliant through SHGs. The Governments of developed and developing countries are taking measures for women empowerment, providing them better education, employment opportunity and conferring women rights.

The performance of women SHGs in Barhampur Development Block depend on a number of variables. These variables are as follows.

\section{Selection of economic activities:}

For the improvement of the socio-economic activities. As a result of which, rural unemployed youth and women have become self- employed. In the field survey of Barhampur Block, it is revealed that the SHG members of 11 Gaon Panchayats have chosen the economic activities like fishery, textiles and handloom, tailoring, weaving and embroidery, herbal products, domestic food product, interest business, poultry farming and cultivation, etc. The following table-1 represents the key activities of the SHGs

Table 1: Key Activities of the SHGs

\begin{tabular}{|c|c|c|c|}
\hline Sl. No. & Key activities & No of SHGs & Percentage \\
\hline 1 & Fishery & 01 & 4.54 \\
\hline 2 & Textiles and handloom & 05 & 22.72 \\
\hline 3 & Tailoring & 01 & 4.54 \\
\hline 4 & Weaving and embroidery & 03 & 13.63 \\
\hline 5 & Herbal and products & 01 & 4.54 \\
\hline 6 & Interest business & 01 & 4.54 \\
\hline 7 & Domestic food product, & 04 & 18.18 \\
\hline 8 & Poultry farming & 04 & 18.18 \\
\hline 9 & Cultivation & 02 & 9.09 \\
\hline & Total & 22 & 100.00 \\
\hline
\end{tabular}

Source: Field Survey

According to the above table, $22.72 \%$ of SHGs has adopted textiles and handloom sector as their key activity. The lowest percentage $4.54 \%$ of SHGs has adopted fishery, tailoring herbal products, interest based business etc. The percentage of other activities are- weaving embroidery $13.63 \%$, domestic food product $18.18 \%$, poultry farming $18.18 \%$ and cultivation $9.09 \%$.

\section{Reasons for Joining SHGs:}

The aim of the SHGs is to promote savings and to provide credit facilities among the members for the productive and consumption purposes. There are three reasons for joining SHG. These reasons are (a) to improve living standard, (b) to start business and (c) social status. The following fig-1 shows the reasons for joining SHGs

Fig 1: Reasons for Joining SHGs

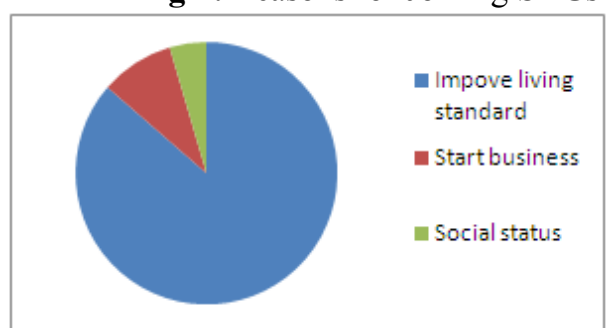

Source: Field Survey 
The data analysis reveals that the highest no. of respondent's .i.e. 95 joined SHG to improve their living standard. The lowest no. of respondents 05 joined SHG to maintain social status. Only 10 no. of respondents joined SHG to start business. In the block, women are lacking in the business because of poor economic condition as well as due to lack of entrepreneurial skill.

\section{Year of Establishment of SHGs:}

An attempt has been made in this survey to know the year of establishment of SHG to indicate the length of the survival of the unit. For this purpose, data have been collected on the year of establishment of SHGs in Barhampur Block. It is depicted in the table-2.

Table 2: Years of establishment of SHGs

\begin{tabular}{|c|c|c|c|}
\hline Sl. No. & Year of establishment & No of SHGs & Percentage \\
\hline 1 & $1997-1998$ & 01 & 4.54 \\
\hline 2 & $1999-2000$ & 01 & 4.54 \\
\hline 3 & $2000-2001$ & 02 & 9.09 \\
\hline 4 & $2001-2002$ & 06 & 27.27 \\
\hline 5 & $2002-2003$ & 03 & 13.63 \\
\hline 6 & $2003-2004$ & 03 & 13.63 \\
\hline 7 & $2004-2005$ & 01 & 4.54 \\
\hline 8 & $2005-2006$ & 02 & 9.09 \\
\hline 9 & $2006-2007$ & 02 & 9.09 \\
\hline 10 & $2007-2008$ & 01 & 4.54 \\
\hline & Total & 22 & 100.00 \\
\hline
\end{tabular}

Source: Field Survey.

It is found in field survey that the largest number of SHGs .i.e. $27.27 \%$ were establishment between 2001-2002 while the lowest of SHGs the number of SHGs .i.e. 4.54\% were establishment between 1997-98, 1999-2000, 2004-05,2007-2008 respectively. It is observed that majority of number of SHGs were started during 2001-02, because this may be due to various schemes undertaken by the government of Assam as well as awareness programmes from SGSY and training arranged by the DRDA in the block

\section{Year of joining SHGs by individuals Members:}

The year of joining SHGs by individual members indicate the interest of members to become selfemployed through SHG economic activities. In field survey, it is found that the number of individual members joining SHG has increased during the period from 2000 to 2001 but declined in 2004-05 and again rises in 2005-06. The year of joining SHG by individual members depicted in the table-3 below.

Table3: Years of joining SHGs by Individual Members.

\begin{tabular}{|c|c|c|c|}
\hline Sl. No. & Year of Joining & No of Respondents & Percentage \\
\hline 1 & $1997-1998$ & 05 & 4.54 \\
\hline 2 & $1999-2000$ & 05 & 13.54 \\
\hline 3 & $2000-2001$ & 15 & 22.72 \\
\hline 4 & $2001-2002$ & 25 & 13.63 \\
\hline 5 & $2002-2003$ & 15 & 13.63 \\
\hline 6 & $2003-2004$ & 15 & 4.54 \\
\hline 7 & $2004-2005$ & 05 & 9.09 \\
\hline 8 & $2005-2006$ & 10 & 9.09 \\
\hline 10 & $2006-2007$ & 10 & 4.54 \\
\hline
\end{tabular}

Source: Filed Survey.

It is found in field survey that the highest number of individual members $22.72 \%$ joined SHG between 2001-02, while the lowest number of individual members 4.54\% joined SHG in 1997-98, 1999-2000, 200405and 2007-08 respectively.

\section{Distribution of Members of SHGs:}

It is important to know total membership of SHG. The membership strength of a SHG shows the merits and demerits of functioning because smaller membership of a group implies better coordination than that f a larger group. Though the concept of SHG depends on membership strength of 10-20 but group formation in the study area is restricted to small number. The distribution of number of members of SHGs has been shown in the following fig-2. 
Fig 2: Percentage of distribution members of SHGs

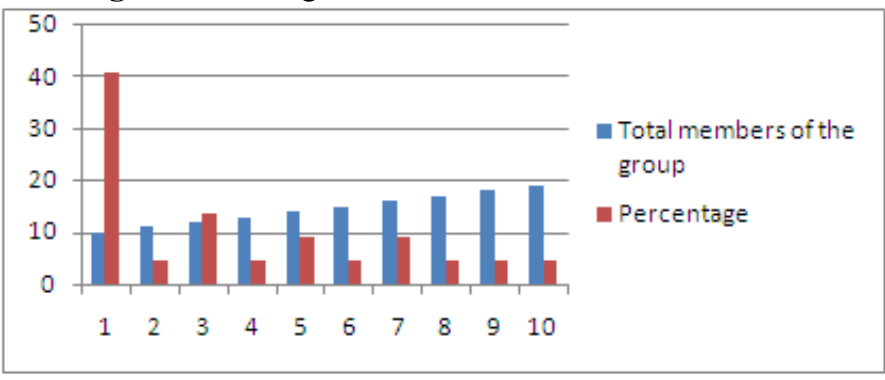

Source: Field survey.

It is found in field survey that the highest number of $40.90 \%$ of SHGs belongs to 10 members group whereas other represents the lowest membership strength.

\section{Rural credit and SHGs:}

Rural credit is one of the most essential inputs to accelerate the development process in the block. Its timely availability in right quantity, at a reasonable rate of interest, provides gainful economic activities in the rural sector. The people of low income groups are deprived of rural credit. Banks generally decline to provide finance to small farmers, marginal farmers, landless labourers, petty artisans, and other landless people as they cannot provide adequate mortgage to the banks. The need of rural people for rural credit is satisfy by the formation of SHG. It has been observed during field survey that the government contribution to SHG is very small, it is very small, and it is represented by the table- 4 .

Table4: Government contribution to SHG.

\begin{tabular}{|c|c|c|c|}
\hline Sl. No. & Amount of loans & No of SHGs & Percentage \\
\hline 1 & $25,000 /-$ & 13 & 59.09 \\
\hline 2 & $50,000 /-$ & 01 & 4.54 \\
\hline 3 & $1,85,000 /-$ & 02 & 9.09 \\
\hline 4 & $2,50,000 /-$ & 03 & 13.63 \\
\hline 5 & Non -loan received & 03 & 13.63 \\
\hline & Total & 22 & 100.00 \\
\hline
\end{tabular}

Source: Field Survey.

It is found in field survey that 59.09\% women SHGs received Rs.25, 000 amount of loan from government, i.e., DRDA and the lowest $4.54 \%$ received Rs.50, 000. It is also found in field survey that $13.63 \%$ women SHGs do not received any amount of loan from government.

The SHG provides various types of their members. The various types of loans provided by SHG are business loan, marriage loan, medical loan, housing loan, cattle loan, agricultural loan. The various types of loan provided by SHG to their members are depicted in the table5 below.

Table5: Types of Loan provided by the SHGs to their Members.

\begin{tabular}{|c|c|c|c|}
\hline Sl. No. & Type of loans & No of respondents & Percentage \\
\hline 1 & Business loans & 18 & 16.36 \\
\hline 2 & Marriage loans & 09 & 8.18 \\
\hline 3 & Medical loans & 32 & 29.09 \\
\hline 4 & Housing loans & 05 & 4.54 \\
\hline 5 & Cattle loans & 07 & 6.36 \\
\hline 6 & Agriculture loans & 24 & 22.82 \\
\hline 7 & Non-loan receiver & 15 & 13.63 \\
\hline & Total & 110 & 100.00 \\
\hline
\end{tabular}

Source: Field Survey.

There is a great demand for credit among the members of SHG in small business, cottage industries, and food processing unit. The SHGs in the study area provide loan to their member for various purposes. The highest percentage of loan, i.e., $29.09 \%$, is provided by SHG to their members for medical purpose. The lowest percentage of loan, i.e., $4.54 \%$, is provided by SHG to their members for housing purpose. It is the general body meeting of SHG which decides the loan disbursement procedure. It is observed in data analysis the all members in the SHG are in need of credit. The distribution of loans to SHGs members is shown in the fig-3. 
Fig 3: Distribution of loans to SHGs Members.

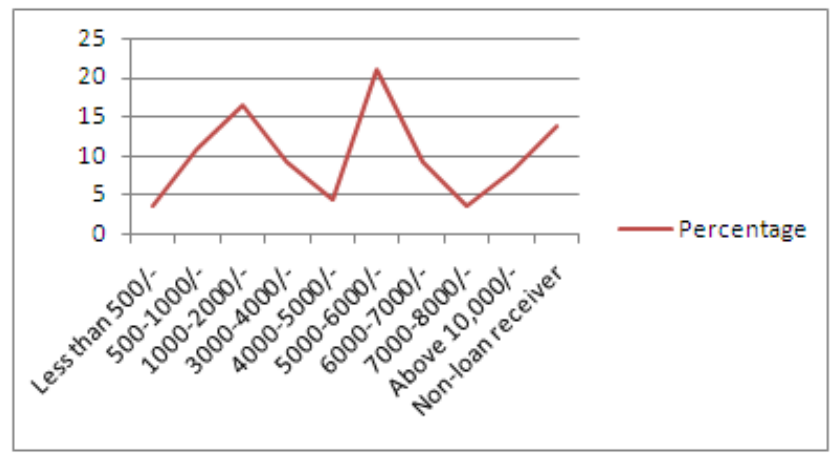

Source: Field Survey.

It is found that the highest percentage, ie. $20.90 \%$, SHGs members received loan amounting to Rs.4000-5000. The lowest percentage, ie.3.63\%, SHG members received loan amounting less than Rs.500 and Rs.7000-8000 respectively. It is also observed in data analysis that $13.63 \%$ members SHG do not received any loan.

The SHGs sanction loan to its members at a reasonable rate of interest. The interest rate of SHGs varies from group. They generally change rate of interest Rs. $1 \%$ to $4 \%$ per month. The members of SHG make repayment of loan by three ways, such as, repayment in time, repayment in advance and repayment not in time. The table-6 shows repayment of loan by SHGs member

Table 6: Repayment of loan by SHGs members.

\begin{tabular}{|c|c|c|c|}
\hline $\begin{array}{r}\text { Sl. } \\
\text { No. }\end{array}$ & Particular & No. of respondents & Percentage \\
\hline 1 & Repayment in time & 73 & 63.36 \\
\hline 2 & Repayment in Advance & 22 & 20 \\
\hline 3 & Repayment not in time & 15 & 13.63 \\
\hline & Total & 110 & 100.00 \\
\hline
\end{tabular}

Source: Field Survey.

In field survey it was found that the members of SHG use the loans for various purposes, either individually or in group as a whole. The highest percentage, ie.66.36\% SHGs members, repay loan in time whereas, the lowest percentage, ie.13.63\% SHG members do not repay loan in time. The small, marginal and landless farmers and other economically underprivileged section of the society need credit to perform day-today activities. They need a small amount of loan ranging from Rs. 500 to Rs. 10,000 for a particular season or period. These types of loans generally not financed by the banking sector. Traditionally, people have to depend on money-lender, traders, commission agents, business community for these types of loans at an exorbitant rate of interest. The growth of SHGs in the last decades has achieved tremendous progress in providing rural credit to the underprivileged section of the rural society.

Most of nationalized and regional rural banks have come forward to provide credit support to SHGs. SHGs has received various assistance and support from DRDA which help them to raise their income generating activities on sustainable basis. For development of credit linkage SHGs passes through a process of gradual evolution during the process, the institute built the capacity of the SHG to manage the selected income generating activity on commercial line and in a scientific manner, the block authority keeps on monitoring the performance of the SHGs and accordingly concerned banks are also involved in the process.

\section{Training of the SHGs members:}

Barhampur Development Block has been conducting training programme on various economic activities at regular intervals with the help and guidance of DRDA, Nagaon to the members of SHG. Training has been generally provided to unemployed youth in the rural area through group formation. The training has changed the outlook of the people and they are motivated to undertake economic activities to improve their economic conditions. It has also helps to reduce poverty and unemployed in the block. Because trained people have started taking economic activities like food preparation, fish and poultry faming, textile and handloom business etc. The distribution of trained members in SHGs has been shown in the table-7 
Table 7: Distributions of Trained members in SHGs

\begin{tabular}{|c|c|c|c|}
\hline Sl. No. & Trained members & No. of SHGs & Percentage \\
\hline 1 & 01 & 02 & 9.09 \\
\hline 2 & 04 & 02 & 9.09 \\
\hline 3 & 06 & 01 & 4.54 \\
\hline 4 & 10 & 06 & 27.27 \\
\hline 5 & 12 & 01 & 4.54 \\
\hline 6 & 13 & 01 & 4.54 \\
\hline 7 & 18 & 01 & 4.54 \\
\hline 8 & 19 & 01 & 4.54 \\
\hline 9 & Non-trained members & 07 & 31.81 \\
\hline & Total & 22 & 100.00 \\
\hline
\end{tabular}

Source: Field Survey.

It is observed in field survey that within a single SHG19 members are found trained, in comparison to this, only one member is found in two self help groups.

\section{Conclusion}

From the study through primary sources it was clear that the women SHGs in bought rural and urban areas are very active in providing income generating activates in Barhampur Development Block in Nagaon District. It can be clear that of the women SHGs are more vital in eradication of poverty for the BPL family. The sample beneficiaries, are gaining employment by adopting own personal skills and home based activities. The micro-finance system is playing a significant role in empowering women through SHGs by the sources of NABARD. The overall analysis of this variable establishes that women empowerment of the block was above average and the hypothesis set that the rural credit helps members of women SHGs to start new business. It is found that majority of women SHGs have taken loan for various economic activities, such as, Cattie framing, poultry framing, fishery, textiles and handloom works, Weaving and embroidery, food processing, agriculture etc. The women SHGs of Barhampur Block are providing rural credit to women members of the SHGs. Therefore, hypothesis is accepted. It would be fruitful to accelerate the development process of the Block at a faster the rate, if mindset of the people is changed. In this era of liberalization, privatization and globalization, women are more conscious for their liberty, rights and freedom, security, social status etc, but till date they are deprived from same; hence, they should be provided with their deserving rights and liberties with dignity. We can conclude that women are part and parcel of our society so, it is essential to empower them.

\section{References}

[1]. Kapoor,Pramilia(2001): "Empowering the Indian women," Ministry of Information and Broadcasting, Government of India.

[2]. Lalithe N and B.S. Nagarejan(2002): "Self- Help Groups in rural Development," Dominant publisher and Distributors, New Delhi.

[3]. Narashimban, Sakuntala (1999) : "Empowerment of Women : An Alternative Strategy for Rural India," Saga Publication India Pvt. Ltd, New Delhi.

[4]. Dasgupta, Rajaram (2005) : "Micro-finance in India, Empirical Evidence, Alternative Model and policy Imperatives," Economic and political weekly, 9 March.

[5]. Manimekalai (2004): “Gross Root Women Entrepreneurship through SHGs,” Peninsular Economist, Vol XII, No 2, Pp: 181-187

[6]. Kartar Sing and Jain (1995): "Evolution and Survival of SHGs" Development Projects.

[7]. Barhampur Block Profile, 2009, BDO, Govt. of Assam.

[8]. District Census Hand Book, Nagaon, Govt. Of Assam.

[9]. Gupta, S (2007): "SHGs effective tools for women empowerment," Development Projects.

[10]. Mansuri, B.B. (2010): "Micro Finance through Self- Help Group- A case study of Bank linkage Programme of NABARD", APJRBM, Volume I, Issue 3, December, P-3.

[11]. Kumar. A (2009): "Self-Help Groups, Women's Health and Empowerment: Global Thinking and Contextual Issues", Jharkhand Journal of Development and Management Studies, Vol.4 No.3 Pp : 2061-2079.

[12]. Anikita Deka (2011): "Determinants of Women's Empowerment in India: Evidence from National Family Health Survey", Society for Social work and Research $15^{\text {th }}$ Annual Conference: Emerging Horizons for Social Work Research, January.

[13]. SaravanaKumar (2012) : "Self- Help Group in socio-economic transformation with special reference to Coimbatore", International Journal of Research in Commerce, Economic and Management, Volume No.2, Issue No.9, September, Pp:87-93

[14]. Angel Anila.A (2012) : "Women Entrepreneurship through Self- Help Groups : A case Study of Tirunelveli District", Tamilnadu International Journal of Research in Commerce, Economic Management, Volume No.2, Issue No.2, February, Pp: 93 -96.

[15]. Ariz. Ahmed, M. (1999): “Women Empowerment' Self-Help Groups,” Kurukshetra April, 47, 7:19, 20 and 49.

[16]. Chatterjee, Sankar (2003): "Networking SGSY, Banks and SHGs initiatives in Uttar Pradesh,” Kurukshetra February, 51, 4:27-29

[17]. Chiranjeevulu T. (2003): "Empowerment Women through Self-Help Groups-Experience in Experiment," "Kurukshetra, March.

[18]. Damayanthi U.T. (1999): "Development of Women and Children in Rural areas- An Impact Study," the Asian Economic Review, August, 41, 2:349-357.

[19]. Jain, Ritu (2003): "Socio-Economic Impact through Self-Help Group", Yojana Vol 47 No. 7 Pp-32.

[20]. Pal, Dr. Mahi (2004): "Social Development of Rural Women in India," Kurukshetra, July 2004, Pp: 40-42.

[21]. Sinha Frances, (2005): “Access, use and contribution of Micro-Finance in India, Finding from a National Study," Economic and Political weekly, April 23.

[22]. Tripathy, K.K., (2004): “Self-Help-Group- A Catalyst of Rural Development,” Kurukshetra, June 2004, Pp. 40-46. 